\title{
Hubertus Blaumeiser, Anna Maria Rossi (red.), Resurrezione di Roma, Dialoghi interdisciplinari su città, persona e relazioni a partire da un testo di Chiara Lubich [Zmartwychwstanie Rzymu. Dialogi interdyscyplinarne o mieście, osobie i relacjach, na podstawie tekstu Chiary Lubich], Roma: Città Nuova, 2017, ss. 247
}

DOl: http://dx.doi.org/10.12775/PCh.2019.036

Niniejsza recenzja odnosi się do piątego tomu serii wydawniczej Studia Szkoły Abba (Studi della Scuola Abbà) publikowanej przez inter- i transdyscyplinarne Centrum Badawcze, które powstało w ramach Ruchu Focolari w 1990 r. ${ }^{1}$ Głównym celem tego Centrum jest badanie mistycznego doświadczenia z 1949 r., określonego jako Paradiso '49 (Raj '49), które było udziałem Chiary Lubich (1920-2008) i grupy osób z nią związanych. Badania te przyczyniają się do wydobywania kategorii z obszaru teologii i szeroko pojętej kultury wypływających ze źródła charyzmatu jedności Chiary Lubich, stanowiąc podstawę kultury jedności².

in Italia (2003-2015). Membro del Centro interdisciplinare di studi Scuola Abbà - Gruppo di ecclesiologia, missiologia e pastorale (Movimento dei Focolari). Contatto: Via Frascati 306, 00040 Rocca di Papa (RM), Italia; e-mail: raul.silva@focolare.org.

${ }^{1}$ Por. http://www.focolare.org/opere-ed-attivita/studio-e-formazione/scuola-abba/. Od 1990 do 2004 r. przedstawiciele Szkoły Abba spotykali się z Chiarą Lubich; od 2004 do 2008 r. koordynatorem instytucji był Giuseppe Maria Zanghí. W związku ze śmiercią Chiary Lubich oraz kilku innych członków na podstawie obowiązującego regulaminu w latach 2008-2014 zespół członków Szkoły Abba został odnowiony, a koordynację prac powierzono Albie Sgariglii; w 2014 r. ponownie odnowiono skład członków, a koordynatorem do dziś jest o. Fabio Ciardi. Od 1998 r. zaczęto powoływać odpowiednie zespoły badawcze dla różnych dyscyplin naukowych, a prace niektórych z nich zostały już opublikowane.

2 Poprzednio wydane tomy w kolejności chronologicznej są następujące: AA. VV., Il Patto del '49 nell'esperienza di Chiara Lubich. Percorsi interdisciplinari (Roma: Città Nuova, 2012); AA. VV., Come frecciate di luce. Itinerari linguistici e letterari nel racconto del '49 di Chiara Lubich (Roma: Città Nuova, 2013); AA. VV., Carisma storia cultura. Una lettura interdisciplinare del pensiero di Chiara Lubich (Roma: Città Nuova, 2014); AA. VV., Guardare tutti i fiori. Da una pagina del '49 di Chiara Lubich (Roma: Città Nuova, 2014). Odniesienia explicite lub implicite do Paradiso '49 (Raj '49) można znaleźć w opublikowanych pismach Chiary Lubich, a także w pracach niepublikowanych. Dotychczas zrealizowane badania, oprócz publikacji w ramach serii Collana della Scuola Abbà, w większości były publikowane w czasopiśmie naukowym Nuova Umanità oraz w innych czasopismach Ruchu Focolari. Ponadto odniesienia oraz fragmenty tych prac można znaleźć w publikacjach 
Od samego początku pojawienia się tego charyzmatu, poprzez późniejsze doświadczenia oraz rozwój Ruchu, Lubich była głęboko przekonana, że - ze względu na fakt Wcielenia Słowa Bożego - charyzmat jedności może wpływać w wymiarze osobistym i społecznym nie tylko na życie duchowe, lecz także na wiedzę. Faktycznie, według Hansa Ursa von Balthasara:

charyzmaty, takie jak św. Augustyna, św. Franciszka czy św. Ignacego, podarowane przez Ducha Świętego, mogą mieć wgląd w samo centrum Objawienia, taki wgląd, który ubogaca Kościół na ogół niespodziewanie, lecz na zawsze. Wszystkie te charyzmaty charakteryzuje ścisły związek pomiędzy inteligencją, miłością i naśladowaniem. Z tego wynika, że Duch Święty jest zarówno boską mądrością, jak i miłością, a w żadnym przypadku nie ogranicza się do samej teorii, lecz zawsze wiąże się z życiową praktyką̧3.

Potwierdzeniem tego może być doświadczenie Chiary Lubich i Ruchu Focolari, w tym Paradiso'49. Życie mistyczki ukazuje wyjątkowy geniusz kobiety w wymiarze eklezjalnym, społecznym i teologicznym oraz szeroko pojętej kultury. Przesiąknięty kreatywnością, zapoczątkował autentyczną szkołę myślenia oraz różne instytucje teologiczne i nauki, stając się inspiracją dla wielu, a także dla samego Kościoła. Istotnie, papież Franciszek, podsumowując swoją wizytę w Mariapoli Renata w Loppiano (k. Florencji, Włochy), która miała miejsce 10 maja 2018 r., opublikował następujący tweet: „Zainspirowani charyzmatem jedności Chiary Lubich szukamy nowych dróg dialogu i komunii".

członków Szkoły Abba lub zespołów dyscyplinarnych, jak np. Michele Zanzucchi (red.), Tutta rivestita di Parola. Il mondo della comunicazione si specchia in Maria (Roma: Città Nuova, 2004); Giuseppe M. Zanghí, Gesù abbandonato maestro di pensiero (Roma: Città Nuova, 2008); Stefan Tobler, Tutto il Vangelo in quel grido. Gesù abbandonato nei testi di Chiara Lubich (Roma: Città Nuova, 2009); Anna Pelli (red.), L'essere come amore. Percorsi di ricerca (Roma: Città Nuova, 2010); Fabio Ciardi, Carismi. Vangelo che si fa storia (Roma: Città Nuova, 2011); Piero Coda, Dalla Trinità. L'avvento di Dio tra storia e profezia (Roma: Città Nuova, 2011); Marie Thérèse Henderson, Il velo sottile. Il mistero della musica (Roma: Città Nuova, 2011); Michele Zanzucchi, Il silenzio e la parola. La luce. Ascolto, comunicazione e mass media (Roma: Città Nuova, 2012); Piero Coda, Julie Tremblay, Alessandro Clemenzia (red.), Il Nulla-Tutto dell'amore. La teologia come sapienza del Crocifisso (Roma: Città Nuova, 2013); Giuseppe M. Zanghí, Leggendo un carisma. Chiara Lubich e la cultura (Roma: Città Nuova, 2015); AA. VV., Il dire è dare. La parola come dono e relazione nel pensiero di Chiara Lubich (Roma: Città Nuova, 2017).

${ }^{3}$ Hans Urs von Balthasar, Teologica, t. III (Milano: Jaca Book, 1992), 22. 
Wkrótce po rozpoczęciu Szkoły Abbà świat akademicki nadał Lubich kilkanaście doktoratów honoris causa w różnych dziedzinach nauki. Pierwszy z nich - w zakresie nauk społecznych (psychologia, socjologia, pedagogika i ekonomia) - został przyznany przez Katolicki Uniwersytet Lubelski 19 czerwca 1996 r., a wśród kolejnych był ten z pedagogiki nadany przez Katolicki Uniwersytet Ameryki (American Catholic University) w Waszyngtonie 10 listopada 2000 r. ${ }^{4}$ Ponadto Chiara Lubich otrzymała różne nagrody i wyróżnienia, zarówno na polu kościelnym jak i świeckim, w tym Nagrodę za „Wychowanie do Pokoju”, przyznaną jej 17 grudnia 1996 r. przez UNESCO 5 .

Recenzowany tom składa się z dwóch części: Tekst i kontekst (s. 13-76) oraz Przemyślenia na temat (s. 77-232). Jest to dokładnie wyrażona hermeneutyka tekstu Lubich w odniesieniu przede wszystkim do wielkich miast (megacities). Publikacja obejmuje także: Przedmowę Fabia Ciardiego (s. 5-12), Podsumowanie (s. 233-234), Uwagi bibliograficzne (s. 235-238) oraz Noty o autorach (s. 239-242).

Książka jest wynikiem dialogu interdyscyplinarnego ${ }^{6}$ prowadzonego przez trzy lata (2014-2017) nad tekstem Chiary Lubich z października 1949 r. zatytułowanym Zmartwychwstanie Rzymu. Brało w nim udział 28 ekspertów $\mathrm{z}$ różnych obszarów nauki: od teologii (biblijna, systematyczna, duchowości, ekumeniczna) po nauki humanistyczne (socjologia, pedagogika, ekonomia, prawo, filozofia, historia, architektura, stosunki międzynarodowe, polityka, psychologia, lingwistyka i literatura, semiotyka), od nauk przyrodniczych (biologia) do nauk ścisłych (matematyka).

${ }^{4}$ Zob.: Chiara Lubich, ,Lezione per la laurea honoris causa in Pedagogia”, Nuova Umanità 135-136 (2001): 341-352; Chiara Lubich, La dottrina spirituale (Roma: Città Nuova, 2006), 313-319; Chiara Lubich, Educazione come vita, red. A. Vincenzo Zani (Brescia: La Scuola, 2010), 149-158; Centro Chiara Lubich - Istituto Universitario Sophia, Dottorati honoris causa conferiti a Chiara Lubich (Roma: Città Nuova, 2016), 309-329. Wydania polskie: Chiara Lubich, „Charyzmat jedności i pedagogika”, w: Chiara Lubich, Charyzmat jedności (Kraków: Fundacja Mariapoli, Wydawnictwo M, 2007), 313-320. Wieloaspektową wizję pedagogiki w myśli Chiary Lubich można znaleźć w: Chiara Lubich, Educazione come vita, red. A. Vincenzo Zani (Brescia: La Scuola, 2010).

${ }^{5}$ Por. Chiara Lubich, „Nowy styl życia chrześcijańskiego. Przemówienie wygłoszone w UNESCO 17 grudnia 1996 r. z okazji wręczenia Nagrody za «Wychowanie do Pokoju»", w: Lubich, Charyzmat, s. 45-49.

${ }^{6}$ W porównaniu z poprzednimi tomami interdyscyplinarnymi tutaj nowością są opracowania napisane przez wielu autorów, z których każdy w swoim artykule odnosi się do różnych argumentów, jednak widoczny jest autentyczny i właściwy dialog pomiędzy nimi. Natomiast poprzednie książki stanowią zbiór indywidualnych prac badawczych. 
W Przedmowie, zwracając uwagę na rzeczywistość miasta jako „miejsca społecznego współżycia, [...] przedmiotu zainteresowania i badań", Ciardi wyjaśnia następująco cel tej książki: „Także Szkoła Abbà [...] pragnie wnieść swój istotny wkład w tym zakresie, poprzez tę publikację. Czyni to, analizując jedno z najsłynniejszych pism Chiary Lubich" (s. 6). Następnie, po wyjaśnieniu zastosowanej metody, stwierdza: „poprzez tę książkę chcemy podzielić się z czytelnikiem wynikami pracy badawczej prowadzonej aktualnie w ramach Szkoły Abbà" (s. 11).

W tej recenzji ograniczam się tylko do trzech perspektyw związanych z naukami o wychowaniu: pedagogicznej, psychologicznej i socjologicznej. W swoim opracowaniu dotyczącym perspektywy pedagogicznej Teresa Boi (s. 193-198) stwierdza:

W zrozumieniu dynamiki uwarunkowań kulturowych, które dotykają istnienia międzyosobowego i społecznego oraz w rozważaniu nad czynnikami, które stanowią fundament historii naszych czasów, pomaga nam refleksja nad możliwościami tworzenia relacji społeczno-edukacyjnych, zdolnych do uniknięcia dezintegracji społecznej, a zarazem sprzyjających budowaniu trwałych synergii w społeczeństwie. Solidną podstawą do stworzenia aktywnego i odpowiedzialnego obywatelstwa jest edukacja w zakresie zachowań prospołecznych oraz międzykulturowa formacja człowieka otwartego na innych, będącego w stanie przyjąć drugiego; człowieka dialogu, patrzącego i widzącego wokół siebie innych: człowieka-świat (uomo-mondo). W różnych kontekstach, poznawcza zdolność spojrzenia miłości, inspirowana nowością aktywnego życia i skutkująca jednoczącą miłością, wypracowuje postawy pedagogiczne oraz sposoby działania zdolne do wytworzenia nie tylko indywidualnego i organizacyjnego upodmiotowienia, ale także upodmiotowienia wspólnotowego (s. 194).

Boi przedstawia następnie cztery doświadczenia inspirowane myślą Chiary Lubich, zrealizowane w Meksyku, Serbii i Słowenii, stwierdzając:

Inwestowanie w przyszłość poprzez integralną formację nowych pokoleń jest „misją” tych szkół, które oferują projekt życia wysokiej jakości, z konkretnym programem, który oprócz promowania rozwoju umiejętności poznawczych i komunikacyjnych, poprzez dialog i pracę zespołową, promuje samoświadomość, rozwój samokontroli i poczucie odpowiedzialności. Podstawowym elementem proponującym upodmiotowienie społeczności, wzajemne zaufanie, więzi odpowiedzialności, wzajemność, w której każdy staje się twórczym protagonistą w budowaniu aktywnego obywatelstwa, jest komunia (s. 198). 
Pomimo że Boi w swoim opracowaniu koncentruje się w istotnej mierze na aspekcie pedagogicznym, wybrzmiewającym w tekście Lubich Zmartwychwstanie Rzymu, uważam, że w jej refleksji brakuje naturalnego i zasadniczego odniesienia do hermeneutyki, którą przede wszystkim sama Lubich wydobyła ze swojego tekstu, tzn. nie ma pewnego rodzaju zestawienia dotyczącego rozumienia i zastosowania jej myśli w środowisku zarówno kościelnym, jak i świeckim; hermeneutyki, która stanowi podstawę działania i ukierunkowania, jakie Lubich pozostawiła założonemu przez siebie Ruchowi. Moim zdaniem takie badania nie zostały jeszcze przeprowadzone na poziomie akademickim. Poza tym powinny one odnosić się do praktyki edukacyjnej oraz podstawowych założeń na temat wychowania, wyrażonych przez Lubich przy różnych okazjach. Co więcej, badania dotyczące praktyki pedagogicznej opartej na myśli Chiary Lubich prowadzone są na poziomie profesjonalnym przez sam Ruchu Focolari za pośrednictwem wielu jego członków. Mówiąc dokładniej, badania te są realizowane przez poszczególne sektory Ruchu takie jak: Nowa Ludzkość, Ruch Gen, Grupa Pedagogiczna ze Szkoły Abba, a także przez szkoły formacyjne, zarówno tzw. zespół EdU (zespół badawczy i dialogu), jak i w ramach studiów II i III stopnia w Instytucie Uniwersyteckim Sophia.

W swoim tekście Lubich (jeśli analizować jej słowa z perspektywy fenomenologicznej) wydaje się wydobywać istotę miasta, traktuje miasto na serio, tzn. jako społeczeństwo według Bożego zamysłu, czyli z podkreśleniem pojedynczej osoby i jej podmiotowości. Pedagogia tak naprawdę dotyczy drogi, którą należy przebyć pomiędzy „tym, co już jest, i tym, co jeszcze nie”. Faktycznie, w perspektywie „trynitarnej” z 1949 r. Lubich patrzy na miasto oczami pedagoga chrześcijańskiego: „I tak Miłość krąży i w sposób naturalny (dzięki zawartemu w niej prawu komunii) wciąga jak rwący potok wszystko, co ci dwaj posiadają, aby uczynić wspólnymi ich dobra duchowe i materialne" (w. 722, s. 20) 7 .

Dialog interdyscyplinarny, jak to wyrażono w tej książce, jest pełen koncepcji, które umożliwiają głębsze badania z perspektywy pedagogicznej, i to nie tylko w odniesieniu do instytucji oświatowych, uznanych i docenionych przez społeczeństwo obywatelskie i polityczne, ale także ze względu na ich autentyczną kreatywność. W tym sensie uważam, że opracowanie Boi można uznać za początek pracy badawczej, co jest zrozumiałe, jeśli weźmiemy pod uwagę to, co wyraził Ciardi w Przedmowie.

${ }^{7}$ Zob. Chiara Lubich, „Zmartwychwstanie Rzymu”, w: Lubich, Charyzmat, s. 253. 
Podczas pisania tej recenzji miałem okazję zobaczyć w telewizji reportaż z Festiwalu Gigantycznych Latawców w Santiago Sacatepequez w Gwatemali. Ich budowa zależy od założonego celu i projektu, dostępnych materiałów oraz szeregu umiejętności i synergii, z wykorzystaniem tego, co każda osoba może dać z siebie. Wraz z ogromnymi latawcami, które mają być przedstawione na wystawie we wspaniałym konkursie artystycznym, budowane są mniejsze latawce, przeznaczone do latania. Zgodnie z przekonaniem potomków Majów jest to sposób na utrzymanie relacji z przodkami. Jest to wydarzenie religijne i społeczne, mające ogromne znaczenie dla tożsamości tego ludu i jego aktywnego obywatelstwa. To jest fascynujące wydarzenie!

Podejście do myślenia pedagogicznego Chiary Lubich zależy przede wszystkim od „wydarzenia”, czyli od praktyki pedagogicznej opierającej się na tej myśli i będącej z nią w ciągłej konfrontacji. U Lubich myśl i życie są jednym, dlatego ona wyrażała swoje pedagogiczne myślenie słowami i czynami, pozwalając ich doświadczyć, ujawniając przez to swoim rozmówcom ich istotę. Ale ona sama była w stanie przyjmować - powiedziałbym, w sposób genialny - wkład każdego ze swoich rozmówców tak dalece, że czuła się wyrażona przez nich, jakkolwiek w wymiarze „eschatologicznym” (już i jeszcze nie). To właśnie potwierdza św. Augustyn w swoim De catechizandis rudibus (Początkowe nauczanie katechizmu) ${ }^{8}$ - mówca słucha tych, którzy słuchają. Co oznacza uznanie obecności drugiego w języku, który jak podkreśla papież Franciszek - ma wymiar potrójny: umysłu, serca i rąk.

Jako że niniejsza recenzja skierowana jest zwłaszcza do czytelników zainteresowanych naukami o edukacji, pragnę skierować ich uwagę także na dwie pozostałe perspektywy przedstawione w książce, a mianowicie psychologiczną i socjologiczną, nie ograniczając się jednak - ze względu na interdyscyplinarny charakter rozważań - wyłącznie do wkładu ekspertów z zakresu tych dyscyplin, tj. Alessandra Partini (s. 134-139) - odnośnie do psychologii, oraz Gennaro Iorio - odnośnie do socjologii (s. 80-81, 84-87; 97-99; 107-108).

Podsumowując, chciałbym podkreślić, że autorzy recenzowanej książki zrealizowali cel podjętych zadań. Biorąc pod uwagę interdyscyplinarny charakter prezentowanej publikacji, warto zwrócić uwagę na tę jej wartość, czyli otwarcie nowych kierunków do refleksji, które - jak wspomniano rozwiną się z czasem przy udziale ekspertów różnych dziedzin na poziomie akademickim, zarówno wewnątrz Ruchu Focolari, jak i poza nim.

8 Por. Św. Augustyn, Początkowe nauczanie katechizmu, tłum. Władysław Budzik (Warszawa: PAX, 1952). 
Autorzy przedstawili na ogół w sposób jasny i świadomy analizowany problem, stosując język, zgodnie ze wskazaniami samej Lubich, zrozumiały dla wszystkich, uczonych i laików, a zarazem właściwy dyscyplinie naukowej. Faktycznie, w odniesieniu do przekazywania treści duchowych i dotyczących wiedzy Lubich zawsze mówiła, że powinna być wyrażana językiem maryjnym, a zarazem zwyczajnym, ze świadomością, że zrozumienie takich treści zależy nie tylko od stopnia rozwoju formacji intelektualnej, lecz od mądrości, która jest owocem miłości.

Odniesienia bibliograficzne są zadowalające, choć mogłyby być uzupełnione i wzbogacone pozycjami odnoszącymi się do różnych kultur. Jeśli chodzi o grafikę tej książki, chciałbym pogratulować Wydawnictwu Città Nuova opracowania tego tomu, dzięki czemu jego lektura jest wyjątkowo funkcjonalna. Publikacja przedstawia niezaprzeczalną wartość pod względem zarówno podejścia do myśli Chiary Lubich, jak i rozumienia pedagogii chrześcijańskiej w świetle charyzmatu jedności.

Podczas wspomnianej wizyty w Loppiano, oprócz uznania wkładu wychowawczego dzieła Chiary Lubich w tworzenie autentycznej kultury jedności, papież Franciszek rzucił wyzwanie - jako cel do osiągnięcia - „budowania kultury opartej na spotkaniu oraz cywilizacji powszechnej ugody"9. Prezentowana książka może być doskonałym wkładem w realizację tego zadania.

\author{
Raul Silva* \\ ORCID: 0000-0001-8816-8497 \\ Rocca di Papa (Rzym), Włochy \\ Ttumaczenie: Stanisław Grochmal, \\ Mariola Teresa Kozubek
}

9 Francesco, "Incontro con la comunità del Movimento dei Focolari. Sagrato del Santuario Maria Theotokos a Loppiano (Firenze) Giovedì, 10 maggio 2018”, https://w2.vatican. $\mathrm{va} /$ content/francesco/it/speeches/2018/may/documents/papa-francesco_20180510_visita-loppiano-focolari.html (Vatican: Libreria Editrice Vaticana, 2018).

* Raul Silva, portugalski teolog, były wykładowca Papieskiego Uniwersytetu Katolickiego w Rio Grande do Sul w Brazylii (2000) oraz w Międzynarodowym Instytucie Mystici Corporis w Loppiano we Włoszech (2003-2015). Członek Interdyscyplinarnego Centrum Badań Scuola Abbà - Zespół Nauk Eklezjologicznych, Misjologicznych i Pastoralnych (Ruch Focolari). Adres: Via Frascati 306, 00040 Rocca di Papa (RM), Italia; e-mail: raul.silva@, focolare.org. 